\title{
ANGIOTENSIN II RECEPTOR TYPE 1 EXPRESSION IN PATIENTS WITH MULTIFOCAL ATHEROSCLEROSIS
}

\author{
Mykhailichenko I.S.
}

\begin{abstract}
Local expression of rennin-angiotensin system (RAS) components significantly increases in patients with arterial hypertension and atherosclerosis with or without elevation of RAS activity in the blood. Our objectives was to assessment and compare the expression level of angiotensin II type 1 receptor in the smooth muscle cells in arteries of patients with multifocal atherosclerosis and the role of local angiotensin II receptor type 1 (AT1R) expression in the disease progression. The study results suggest that the tissue RAS activity increases inhomogeneously among patients. It was interestly that AT1R expression levels in intact arteries does not differ of those in atherosclerotic arteries. Most of patients had expression of angiotensin II type 1 receptor in smooth muscle of arteries; strong elevation had $43,8 \%-50,0 \%$. Our study suggest of role of local RAS activity, but we proposed existence of another than only angiotensin II type 1 receptor mechanisms of low or high susceptibility of arteries to atherosclerosis in patient with multifocal atherosclerosis.
\end{abstract}

Key words: renin-angiotensin system, angiotensin II receptor type 1, multifocal atherosclerosis.

M. Gorky Donetsk National Medical University, Donetsk, Ukraine.

Corresponding author. Mykhailichenko I. S., e-mail: klassiki@inbox.ru

RAS - rennin-angiotensin system, AT1R - angiotensin II receptor type 1, CVD cardiovascular disease, Ang II - angiotensin II, BP - blood pressure, SMC smooth muscle cell, $\mathrm{AH}$ - arterial hypertension, IHC - immunohistochemical.

Received December 09, 2015

Revision received December 11, 2015.

Accepted December 18, 2015.

\section{ЭКСПРЕССИЯ РЕЦЕПТОРОВ АНГИОТЕНЗИНА ІІ 1-ГО ТИПА У ПАЦИЕНТОВ С МУЛЬТИФОКАЛЬНЫМ АТЕРОСКЛЕРОЗОМ}

Михайличенко Е.С.

В патогенезе кардиоваскулярной патологии одну из ведущих ролей играет ренин-ангиотензиновая система (РАС). При этом в развитии атеросклероза и ремоделирования сосудов особо важное значение имеют компоненты тканевых, локальных РАС. В данном исследовании мы изучали плотность рецепторов ангиотензина II 1-го типа (AT1R), как маркера активности РАС, в гладкомышечных клетках сосудов (ГМКС) у пациентов с мультифокальным атеросклерозом и артериальной гипертензией. Оказалось, что только у 50\% пациентов наблюдалась высокая плотность AT1R в ГМКС, при этом в маммарных артериях, наименее подверженных атеросклерозу, плотность AT1R не отличалась от таковой в сосудах, пораженных атеросклерозом. Механизмы, определяющие неоднородность активности

Renin-angiotensin system (RAS) plays a central role in pathogenesis of cardiovascular diseases (CVDs) [1]. Its primary biologically active component angiotensin II (Ang II) mediates both direct physiological effects of RAS as vasoconstriction and blood pressure (BP) regulation and pathophysiological ones affecting the function of practically all organs including heart, kidneys, blood vessels, and brain. So, Ang II plays an important role in development of hyperplasia and hypertrophy of smooth muscle cells (SMC) of vessels, hypertrophy and remodelling of myocardium, arterial hypertension $(\mathrm{AH})$, myocardial infarction, atherosclerosis, in-stent restenosis, and renal fibrosis [2, 3]. Here, most of AngII pathological effects occur via its interaction with angiotensine II type 1 receptors (AT1R). Traditionally, RAS is considered as circulating hormonal system, however, according to current data, except the circulatory RAS, majority of organs and tissues do also have local, tissue RAS that possess local paracrine and autocrine functions where the тканевых компонентов РАС у пациентов с атеросклерозом, требуют дальнейшего изучения.

Российский кардиологический журнал 2016, 4 (132), Англ.: 187-189 http://dx.doi.org/10.15829/1560-4071-2016-4-eng-187-189

Ключевые слова: ренин-ангиотензиновая система, рецептор ангиотензина II 1-го типа, мультифокальный атеросклероз.

Донецкий национальный медицинский университет им. М. Горького, Донецк, Украина.

tissue RAS components express and function independently of circulatory RAS [4]. In this connection, study of local RAS activity and their contribution into development of CVDs is a research area of current interest. As the expression level of AT1R determines the biological efficiency of Ang II and RAS in whole, study of AT1R density and mechanisms of its regulation poses an especial interest.

Objective: assessment and comparing the activity of tissue RAS based on the assessment of level of AT1R expression in SMC of intact and atherosclerotic arteries of patients with multifocal atherosclerosis.

\section{Material and methods}

We investigated 30 resected medium caliber arteries. 16 arteries of patients with low extremity atherosclerosis collected during vascular reconstructive operations made the first study group. The second group consisted of 14 intact mammary arteries collected during coronary bypass 


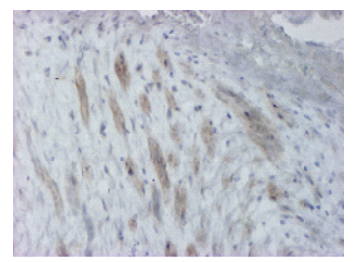

Figure 1. Focal IGH expression of AT1R in human atherosclerotic artery. Visualization system DAKO Envision Flex+ x150.

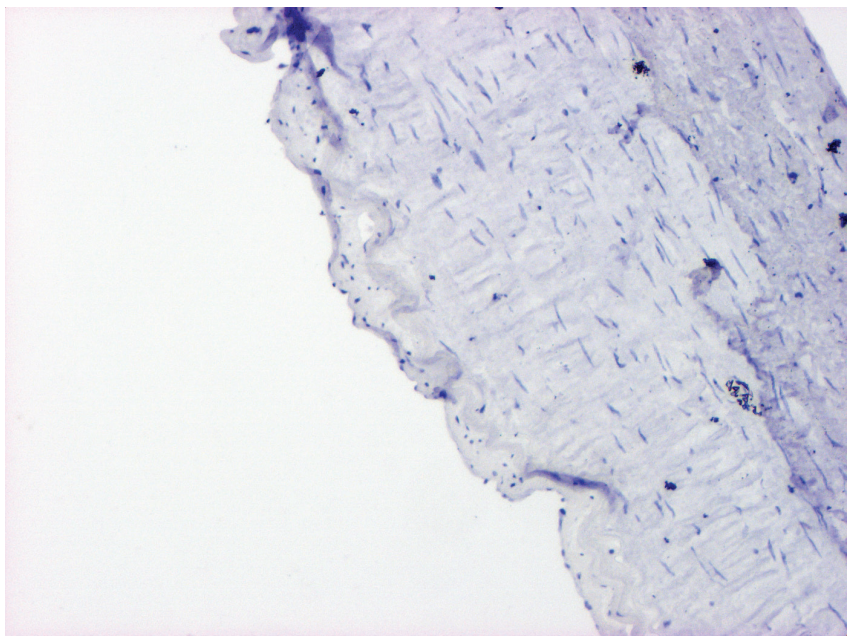

Figure 2. Lack of $I G H$ expression of $A T 1 R$ in human atherosclerotic artery. Visualization system DAKO Envision Flex+ x75

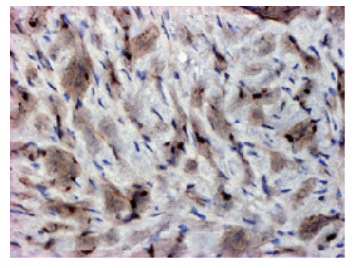

Figure 3. Strong IGH expression of AT1R in human atherosclerotic artery. Visualization system DAKO Envision Flex+ x75

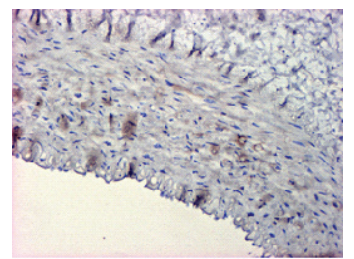

Figure 4. Focal IGH expression of AT1R in human mammarian artery. Visualization system DAKO Envision Flex+ x75.

in subjects with multi-vessel coronary disease. The groups did not differ significantly by age, gender, arterial hypertension severity, concomitant disorders (diabetes mellitus, obesity etc.). Multifocal atherosclerosis was detected at all patients according to the data of arteries ultrasound examination and angiography.

Collected material was put into neutral buffered formalin solution $10 \%(\mathrm{pH} \mathrm{7,4)}$ and fixed during 24 hours. After dehydration, the pieces were poured into paraffin according to standard techniques. On rotation microtome Shandon Finesse 325 (Thermo Scientific, USA) serial histological sections $4 \mathrm{mcm}$ thick that were further stained with hematoxylin and eosin according to standard techniques. Degree of expression of 1 type receptor to angiotensine II in muscular layer of vessels was studies with immunohistochemical (IHC) techniques. For IHC research, sections were placed onto adhesive - coated slides Super Frost Plus (Menzel, Germany). To retrieve the antigens, rehydrated sections underwent thermal treatment in solution Target Retrieval Solution (DAKO, Denmark) with use of microwave oven Samsung CE118KFR. After blocking of non-specific binding of proteins with protein block (DAKO) and of endogenous peroxidase activity with peroxidase block (DAKO) primary antibodies were applied. The polyclonal antibodies to Anti-AGTR1 (SIGMA, Sweden) were used. Visualization of primary antibodies was performed with the aid of high-sensitivity polymer detection system EnVision FLEX+ (DAKO). As a substrate for horseradish peroxidase $\mathrm{DAB}+(\mathrm{DAKO})$ was used. Specimens were additionally stained with Mayer's hematoxylin. Next, the stained sections were mounted into semi-synthetic medium Eukit (Kaltek, Italy).

Microscopic examination of specimens and morphometric studies were performed with microscope Olympus AX70 Provis (Olympus, Japan) with the support of image analysis software application Analysis 3.2 Pro (Soft Imaging, Germany) according to recommendations of the software developer. In each case of IHC research the expression of Anti-AGTR1 marker as brown cytoplasmic or membrane staining was studied in 30 fields of view with magnification $\mathrm{x} 200$. Staining intensity of angiotensin II receptors in muscular layer of arteries was assessed semiquantitatively by percentage of positive cells according to 3-level scale: «-», negative (lack of positively stained cells); «+», focal or weak expression ( $<50 \%$ of positive cells); «++», diffuse or strong positive reaction ( $>50 \%$ of positive cells) [5].

\section{Results}

Similar results were achieves in both groups. In 8 arteries of the first group $(50,0 \%)$ the low or focal expression $(+)$ of AT1R was found (Figure 1), in other 7 arteries the AT1R expression $(43,75 \%)$ was strong. There was no AT1R expression (-) in 1 case $(6,25 \%)$ (Figure 2). In the 2 nd group in $50 \%(\mathrm{n}=7)$ of arteries the strong AT1R expression was found (Figure 3), in other $50 \%$ of cases $(n=7)$ the AT1R expression was focal (Figure 4) or weak (Figure 5). Thus, significant AT1R expression was observed not depend on the studied vascular bed $(\mathrm{p}>0,05)$ (Table 1).

\section{Conclusion}

The study results suggest that the tissue RAS activity increases inhomogeneously among patients with multifocal atherosclerosis. AT1R expression levels in intact arteries does not differ of those in atherosclerotic arteries. AT1R 
Table 1

\section{Comparison of 2 groups. Chi-square test. Chi-square $=0,94$}

\begin{tabular}{|c|c|c|c|c|}
\hline \multirow{2}{*}{\multicolumn{2}{|c|}{ Index }} & \multicolumn{2}{|c|}{ Frequency of occurrence, abs. $(\% \pm m \%)$} & \multirow[t]{2}{*}{ Significance level of difference, $p$} \\
\hline & & 1st group ( $n=16$ ) & 2nd group $(n=14)$ & \\
\hline \multirow[t]{2}{*}{ AT1R expression } & - & $1(6,3 \pm 6,1)$ & - & \multirow[t]{2}{*}{0,626} \\
\hline & ++ & $7(43,8 \pm 12,4)$ & $7(50,0 \pm 13,4)$ & \\
\hline
\end{tabular}

expression in SMCs is negative in patients with severe atherosclerosis that puts under the doubt the key role of RAS in pathogenesis of vascular remodelling in some cases. Further researches of mechanisms that influence the level of RAS tissue components expression are needed. The studies of low susceptibility cause of mammary arteries to atherosclerosis in high RAS activity in the presence of severe lesions of arteries at other sites are required. Probably the study of efficacy of RAS inhibitors in patients with various AT1R tissue expressions will allow to develop the prognostic methods of therapy efficiency and to individualize the treatment. Most of patients had expression of angiotensin II type 1 receptor in smooth muscle of arteries; strong elevation had $43,8 \%-50,0 \%$. Our study suggest of role of local RAS activity, but we proposed existence of another than only angiotensin II type 1 receptor mechanisms of low or high susceptibility of arteries to atherosclerosis in patient with multifocal atherosclerosis.

\section{References}

1. De Giusti VC, Ciancio MC, Orlowski A, Aiello EA. Modulation of the cardiac sodium/ bicarbonate cotransporter by the renin angiotensin aldosterone system: pathophysiological consequences. Front. Physiol. 2013; 4: 411.

2. Thomas WG, Mendelsohn FAO. Angiotensin receptors: form and function and distribution. International Journal of Biochemistry and Cell Biology. 2003; 35, 6: 774-9.

3. Wynne BM, Chiao CW, R. Webb C. Vascular Smooth Muscle Cell Signaling Mechanisms for Contraction to Angiotensin II and Endothelin-1. J. Am. Soc. Hypertens. 2009; 3, 2: 84-95.

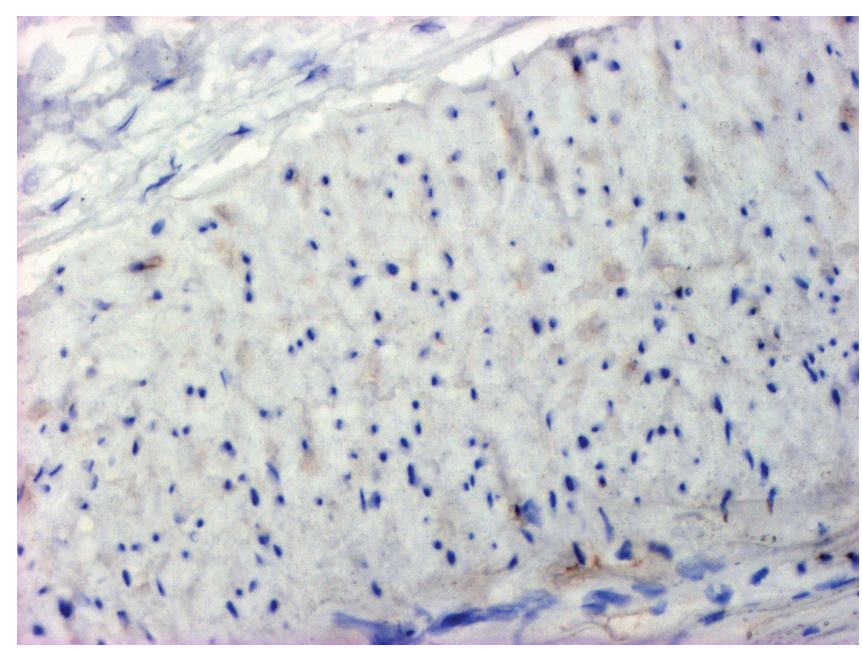

Figure 5. Weak IGH expression of AT1R in human atherosclerotic artery. Visualization system DAKO Envision Flex+ x75.

4. Crowley SD, Coffman TM. Recent advances involving the renin-angiotensin system. Exp. Cell. Res. 2012; 318, 9:1049-56.

5. Suganuma $\mathrm{T}$, Ino $\mathrm{K}$, Shibata $\mathrm{K}$, et al. Functional expression of the angiotensin II type 1 receptor in human ovarian carcinoma cells and its blockade therapy resulting in supression of tumor invasion, angiogenesis, and peritoneal dissemination. Clin. Cancer Res. 2005; 11: 2686-94. 